\title{
OBITUARY
}

\section{LIEUTENANT WILFRED PARKE, R.N.}

Lieutenant Wilfred Parke, R.N., who was killed while flying with Mr. A. Arkell Hardwick as passenger, on the 70 H.P. Handley Page monoplane at Wembley on December 15th, was generally recognised as being the most experienced of our naval aviators, as well as one of the best fliers. That he should have met his death in such a simple accident is one of those curious vagaries of fate such as may be the lot of any man. One knows of men who have hurted for years being killed through their horses falling on an ordinary road.

Wilfred Parke was the son of the Reverend A. W. Parke, now Rector of Uplyme, Dorset, and he was born in Devonshire on April 1st, 1889. His early experience of flying was received at Brooklands at the old Avro School, which has given us so many of our finest pilots, among them Howard Pixton, F. R. Raynham, Ronald Kemp, Captain Beattie, and Louis Nöel. Owing to an accident to the Avro School machine he actually took his certificate on a Bristol biplane, the certificate being No. 73, granted on April 25th, 1911, so that he was quite one of the older group of pilots, the men who taught themselves how to fly and were not rushed through their training in a few hours by school instructors.

After taking his certificate he flew on a great variety of machines, but more on the Avro than on any other make, and probably the finest performance in his career was his putting the "enclosed" Avro, with the 60 H.P. Green engine, through the Military Aeroplane Competition during the last few days of the trials, atter it had been practically destroyed by ar. unlucky landing in the first week. In spite of the worst possible weather, and dogged by bad luck, even to the extent of having his climbing test spoiled by a mysterious down-draught, he managed to get through the tests in excellent style.

After the competition he was appointed to the Naval Wing of the Royal Flying Corps, and soon became one of the most generally and genuinely liked members of the corps, for his personal charm won for him the regard of officers and men alike, while his pluck and ability as a flier commanded their respect.

While on week-end leave he regularly journeyed to London to fly any new machine whose maker would allow him to do so, his idea being that the more experience he could acquire the more valuable he would be to the Service. I rather gathered from him that he had a tacit understanding with the authorities that no objection would be raised to his gaining experience in this way so long as his name did not become too prominent in connection with unofficial flights, consequently few people outside the regular frequenters of Hendon and Brooklands knew how much fine flying he did. Also, only a few of his personal friends knew that during the last few weeks of his life he was engaged on special experimental work away from Eastchurch altogether, and that the results of those experiments, which were unfortunately cut short by his death, may have far-reaching results in the future.

While at Eastchurch he flew practically every machine in the place, but his experimental work afterwards was done on a new type Short biplane, with which he achieved excellent results. During the last month or two of his life his week-end flying was done on the Handley Page monoplanes, first on the 50 H.P. and then on the 70 H.P. On both of these he specialised on passenger-carrying, and I have seen him take up over a dozen passengers one after the other during a short December afternoon.

A few months before his death he began to keep a private record of his experiences and impressions of the various machines he had flown, but unhappily he only had time to record the performances of half a dozen machines, though such record as he has left is of very great value indeed.

Personally, Wilfred Parke was one of those fortunate beings who make firm friends wherever they go. His habit of speaking his mind freely, regardless of consequences, might have made enemies for him had it not been for the fact that his opinions had so 
much sound judgment behind them that they were in most cases incontrovertible, and the very forcefulness with which he expressed himself removed any sting from his words. His mental activity and strength of character would indubitably have won for him a high place in the King's Service had he been spared, and his death removes a personality which cannot be replaced.

C.G.G.

\section{ALFRED ARKELL HARDWICK}

Alfred Arkell Hardwick was born in the year 1878 in London, and his career throughout was of a most romantic description. At the age of some fourteen years he went as an apprentice to sea, and sailed several voyages from this country to Australia, South Africa, and Japan-serving altogether three years. On one occasion when rounding Cape Horn he was washed overboard, and was only soved by the returning wave carrying him back on deck again. When he was between seventeen and eighteen he landed in South Africa and there-disappointed in a venture he had undertaken with a friendjoined the Mashonaland Police, serving through the Mashonaland campaign. He gained a medal and bar for this-being mentioned in dispatches. Shortly afterwards we find him in Egypt, where he was employed on the Nile Irrigation Works. There meeting a friend, Mr. George West, he later accompanied him south when the Boer War broke out. The next two or three years find him big-game hunting and exploring in Central Africa, and on his return to England he wrote a book detailing his experiences, entitled: "An Ivory Trader in North Kenia," published by Longmans, Green \& Company. As a result of the experience gained he started a Nigerian Trading Company, and went out to West Africa for "The African World" as a special commissioner. Returning from there he went to Morocco with a small party of journalists accompanying Mr. Laurence Harris, of "The Graphic." On his return from Morocco he went to America and was connected with Dr. Spratt, of Coatsville. After a year or so out in the States, Hardwick returned to England and joined Handley Page, Limited, and was with them as Assistant Manager from the early part of 1911 until his death.

Of genial personality, Hardwick had a winning manner that made great friends wherever he went-their circle is world-wide. His keenness for aviation knew no bounds, and he made his work his hobby in every sense of the word. To those who had the pleasure of working with him and of knowing his cheery personality-always helping, always seeking to improve-the loss is indeed a great one. His unfailing belief in the immense future of aviation was such that if he had felt that the sacrifice of his life would in any way have aided the final accomplishment of the mastery of the air, he would willingly have laid it down for so high a purpose.

F.H.P.

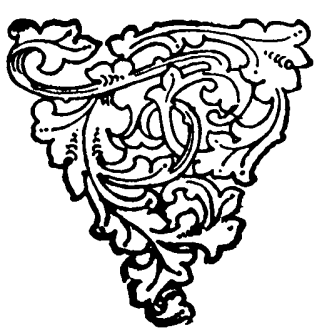

